\title{
The Experience of Employing the Slave Narrative Genre in Describing the History of the Caucasus
}

\author{
A. Yu. Peretyatko
}

For citation: Peretyatko A. Yu. The Experience of Employing the Slave Narrative Genre in Describing the History of the Caucasus. Vestnik of Saint Petersburg University. History, 2021, vol.66, issue 1, pp. 302-313. https://doi.org/10.21638/11701/spbu02.2021.119

The genre of the slave narrative is unique, and is essential to African-American culture. Yet, up to now, personally written stories describing the journey to freedom traveled by "heroic slaves", writings that could well qualify as nonfiction, have received little attention outside of the US and UK. This makes all the more interesting the attempt by prominent Russian historian A. A. Cherkasov to employ the slave narrative genre in describing the history of the Caucasus, undertaken in his collection of documents "Circassian Slave Narratives". This review of the collection attempts to analyze the phenomenon of the slave narrative and determine the degree to which it could be transposed to Russia. It is shown that while a portion of the documents published by A. A. Cherkasov, specifically interviews with slaves who escaped from Russia to Circassia, do seem to fit in with the slave narrative genre in theme, most of the Russian-Circassian slave narratives are completely different from classic slave narratives in content and style. These are not publicistic memoirs written for abolitionist purposes but documentation maintained to keep records of fugitives. In the end, the author of the article draws the conclusion that it is impossible to have an exact analogue of the slave narrative for Russian history as the figure of the heroic slave is not something that is typical for Russian history. Accordingly, despite the fact that fugitive slaves' testimonies were widely written down at the time, as was the case in Circassia, the outcome was a completely different type of writing typologically. However, if the slave narrative is viewed in a broad sense, as an aggregate of first-hand slave accounts that can help provide the reader with a comprehensive documentary picture of the life of actual slaves, "Circassian Slave Narratives" may well be considered a worthy representative of the genre. A. A. Cherkasov provides 180 interviews with slaves and over 1,000 thematically contiguous record-keeping documents, which offer a unique insight into Circassian slavery specifically. Consequently, while it is hardly possible to use the classic slave narrative in describing Russian history, there may be considerable potential in its creative reconceptualization, as has been well substantiated by A. A. Cherkasov.

Keywords: slavery, slave narrative, publication of documents, Caucasian War, Circassia.

Artyom Yu. Peretyatko - PhD (History), Joint Laboratory of the International Network Center for Fundamental and Applied Research, 1150, Connecticut Av., Washington, NW, STE 900, District of Columbia, 20036, USA; Volgograd State University, 100, pr. Universitetsky, Volgograd, 400062, Russian Federation; ArtPeretatko@yandex.ru

Артем Юрьевич Перетятько - канд. ист. наук, Международный сетевой центр фундаментальных и прикладных исследований, США, 20036, округ Колумбия, Вашингтон, NW, STE 900, 1150, Коннектикут авеню; Волгоградский государственный университет, Российская Федерация, 400062, Волгоград, пр. Университетский, 100; ArtPeretatko@yandex.ru

(C) St. Petersburg State University, 2021 


\section{Опыт применения жанра slave narrative к описанию истории Кавказа}

\section{А. Ю. Перетятько}

Для цитирования: Peretyatko A. Yu. The Experience of Employing the Slave Narrative Genre in Describing the History of the Caucasus // Вестник Санкт-Петербургского университета. История. 2021. Т. 66. Вып. 1. С.302-313. https://doi.org/10.21638/11701/spbu02.2021.119

Жанр slave narrative (традиционно переводится на русский язык как «невольничьи повествования») относится к числу уникальных и одновременно ключевых для культуры афроамериканцев. А вот за пределами США и Великобритании истории о пути к свободе «рабов-героев», записанные ими самими и претендующие на документальность, не получили особого распространения. Тем интереснее попытка известного историка А.А. Черкасова применить данный жанр к описанию истории Кавказа, осуществленная в сборнике документов «Черкесские невольничьи повествования». В рецензии на сборник предпринимается попытка проанализировать сам феномен slave narrative и понять, насколько он может быть перенесен на российскую почву. Автор показывает, что, хотя в сюжетном плане часть опубликованных А.А. Черкасовым документов повторяет канву slave narrative, представляя собой опросы сбежавших в Россию из Черкесии рабов, по содержанию и стилю изложения русско-черкесские невольничьи повествования совершенно иные. Это не публицистические мемуары, написанные с аболиционистскими целями, но делопроизводственные бумаги, ведшиеся для учета беглецов. В конечном счете автор приходит к выводу, что полный аналог slave narrative о российской истории невозможен просто потому, что для истории России не характерна фигура «раба-героя», и даже когда показания беглых рабов массово фиксировались, как в случае Черкесии, результатом становились типологически совершенно иные тексты. Однако если трактовать slave narrative в широком смысле - как рассказы самих невольников, формирующие у читателя масштабную документальную картину их жизни, то «Черкесские невольничьи повествования» могут считаться достойным представителем данного жанра. А.А. Черкасов опубликовал 180 опросов рабов и более 1000 тематически смежных делопроизводственных документов, раскрывающих специфику именно черкесского рабства. Таким образом, хотя использование модели классических slave narrative для описания российской истории едва ли возможно, их творческое переосмысление имеет большие перспективы, что вполне доказал А. А. Черкасов.

Ключевые слова: рабство, slave narrative, невольничьи повествования, публикации документов, Кавказская война, Черкесия.

As defined by I. M. Udler, a prominent Russian researcher of the slave narrative genre, it is a "unique Anglo-American nonfiction-publicistic genre"1. The scholar is convinced that its significance for African Americans is undeniable. As shown by I. M. Udler in a whole set of her articles, the "slave narrative" archetype remains highly significant to present-day African-American writers too. There is even a new term - "neo-slave narrative" - being used (initially employed to denote "modern accounts of escaping from slavery based on oral tradition", it is used today more broadly) ${ }^{2}$. Without dwelling on the finer details of how the slave narrative evolved, it is just worth noting that, for the most part, the

${ }^{1}$ Udler I. M. Stanovlenie i evoliutsiia dokumental'no-publitsisticheskogo zhanra "nevol'nich'ego povestvovaniia" v XVIII-XIX vekakh // Znak: problemnoe pole mediaobrazovaniia. 2009. Vol. 1, no. 3. P. 88.

${ }^{2}$ Ibid. P. 92; Udler I. M. "Nevol'nich'i povestvovaniia" v kul'ture i istorii SShA // Mirovaia literatura v kontekste kul'tury. 2009. No. 4. P. 17. 
genre is eulogistic, reaching its pinnacle in the works of "the school of heroic fugitives"3. The reasons for this are quite apparent. As noted by scholar Yu. V. Stulov, slave narratives were a "key tool used by the abolitionists", serving, essentially, to depict the heroic "journey from slavery to freedom, from darkness to light"4. In the same vein, back in the first half of the $20^{\text {th }}$ century, a prominent historian of slavery U. B. Phillips ventured the assertion that "ex-slave narratives in general $\langle\ldots\rangle$ were issued with so much abolitionist editing that as

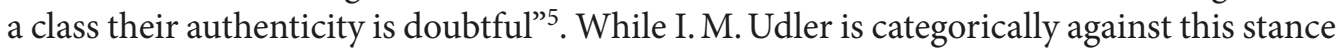
because "the abolitionists aspired, in the name of goals and objectives pursued by the abolitionist movement, to perfect, stenographic accuracy in recording information", there may be more importance in recognizing the actual fact that the opponents of slavery were building a corpus for the slave narrative ${ }^{6}$. Eventually, the genre would become a source of pride, "all" (per I.M. Udler) to African-American literature and publicistic writing, and it is on its foundation that there would emerge the first work of African-American prose fiction, distinctively entitled "The Heroic Slave"

Theoretically, Russian history appears to offer a plethora of stories for works of the slave narrative genre. However, what largely hampers the transposing of this genre to Russia is the distinctive pathos and model of the American texts. Specifically, I. M. Udler juxtaposes the classic exemplar of the slave narrative "The Interesting Narrative of the Life of Olaudah Equiano, or Gustavus Vassa, the African" written, apparently, by Olaudah Equiano himself, with "The Autobiography of One of the Unknown Spreaders of Literacy among the People" written by a Russian serf named I.P. Spekhin. The researcher points out a similarity between the autobiographical narratives of Equiano and Spekhin - during their adventures they both were sailors in the Atlantic. However, other than that, the stories are diametrically opposed to each other in content. O. Equiano sailed as a slave, but, thanks to his talents, he managed to buy himself out of slavery and eventually became a free respected person. By contrast, I. P. Spekhin was by accident left in London by the crew and later became a free English seaman, but, upon return to his homeland, he would be punished with lashes and exiled to his home village, where he would live a meager existence ${ }^{8}$. It may be suggested that such a difference in storyline is highly emblematic in comparing the figure of the American slave and that of the Russian slave in the $19^{\text {th }}$ century. On the one hand, there is the "heroic slave" who through personal effort achieves freedom and public recognition and later engages in a struggle for the liberation of other slaves. On the other hand, there is the "groaning", yet "sleeping", Russian serf who is ready to bear anything (the imagery is taken from "Thoughts at a Vestibule", a classic poem by N.A. Nekrasov). This kind of figure will be referred to in the present work as "slave martyr".

${ }^{3}$ Udler I. M. Stanovlenie i evoliutsiia... P. 88.

${ }^{4}$ Stulov $I u$. V. Zhanr neo-nevol'nich'ego povestvovaniia v sovremennoi afroamerikanskoi literature // Visnyk of the Lviv University. Series Foreign Languages. 2012. Issue 20, part 2. P. 160.

5 Udler I. M. Afroamerikanskie "nevol'nich'i povestvovaniia" kak dokumental'nyi istochnik istorii rabstva v SShA // Vestnik Cheliabinskogo gosudarstvennogo universiteta. Filologiia. Iskusstvovedenie. 2009. No. 5 (143). P. 118.

6 Ibid. P. 119.

7 Udler I. M. Stanovlenie i evoliutsiia... P. 88, 91.

8 Udler I. M. "Uvlekatel'noe povestvovanie o zhizni Olauda Ekviano, ili Gustava Vazy, afrikantsa. Napisano im samim": problema identifikatsii, russkaia sud'ba i russkie paralleli // Mirovaia literatura v kontekste kul'tury. 2008. No.3. P. 128-133. 
Here, it will be worth touching upon the following important consideration. What is central to the slave narrative genre is the figure of the author, a "heroic slave", and the narrative being at least relatively of a nonfictional nature. The narrator is a worthy, sufficiently educated, and intellectual person, who is on a par with the reader. Tellingly, this group includes J. W. C. Pennington and W. W. Brown, the first African-American historians ${ }^{9}$. This, firstly, may be viewed as logical as only an educated person would be capable of reflecting in written form on their experiences of slavery. Secondly, this way to deliver the slave narrative made it possible to highlight the absurdity of the very idea of the white slave-owners being superior to their slaves. And thirdly, this kind of people simply had what it takes to answer many of the questions for themselves and for the readers. It is in this context that American researcher C.H. Nichols writes: "What does it mean to be another man's property? How does it feel to work without wages, or, as a field hand, coerced into producing another's cotton, corn or sugar, to be forced in all society's arrangements to accept the blight of inferiority? <..> What emotions inflamed their murderous and abortive revolts? When compelled into submission and disingenuous cooperation, what was the nature of their tenuous "adjustment" to slavery? Or, having fled the plantation, what had slavery done to their personality and behavior? These are questions which only the slave himself can directly answer" ${ }^{10}$.

However, these questions could hardly be answered by the Russian "slave martyr". On the contrary, the more oppressed and wretched he was, the stronger was the emotional response elicited by him from the reader. It is not meant to be a generalization suggesting that in the Russian version of the slave narrative a key place in terms of reflections was supposed to be occupied by emotions, and in terms of being nonfiction - by being typical. It is apt here to recall another poem by N.A. Nekrasov, "On the Road", which, essentially, is a slave narrative. However, in the poem, a serf coachman who tells the reader about his dying wife (raised alongside a damsel of noble birth but later sent to the countryside to lead a life of a typical serf) is simply unable to understand the cause of her sorrow and misery. Consequently, slave narratives did not form in Russia a separate genre as they failed to be documented in a proper manner, with their place taken by fictional and standardized stories on serfage written by landlords, a classic exemplar thereof being I. S. Turgenev's collection of short stories "A Sportsman's Sketches".

It is only in our days that an informed attempt has been made at adjusting the slave narrative genre to describing Russian history. In 2020, a prominent Russian historian A. A. Cherkasov (the author of works about the history of slavery in the Caucasus ${ }^{11}$ ) released a collection of documents entitled "Circassian Slave Narratives"12. The scholar pursues the same objective as his American predecessors: "take a look at life $<\ldots>$ through the eyes of captives and slaves"; "provide an opportunity to let the world know what it was like to live as a slave" to actual slaves, not those in southern US states but those in Circas-

${ }^{9}$ Udler I. M. Afroamerikanskie “nevol'nich'i povestvovaniia”... P. 121.

10 Ibid. P. 121.

11 Cherkasov A. A., Ivantsov V. G., Smigel M., Molchanova V.S.: 1) The List of Captives from the Turkish Vessel Belifte as a Source of Information on the Slave Trade in the North Western Caucasus in the Early $19^{\text {th }}$ century // Annales. Series historia et sociologia. 2017. Vol.27. Iss. 4. P. 851-864; 2) Evolution of the Institution of the Slave Trade in the Caucasus in the IV-XIX centuries // Bylye Gody. 2018. Vol. 50. Iss. 4. P. 1334-1346.

12 Cherkasov A. A. The Circassian Slave Narratives (A Documentary Collection) // Bylye Gody. 2020. Vol. 57-1. Iss. 3-1 (Special issue). 
$\operatorname{sia}^{13}$. It is to be noted that the researcher's choice of genre is pretty shrewd for the State Archive of Krasnodar Krai holds hundreds of documents on Circassian slavery, including materials from interviews with fugitive slaves ${ }^{14}$. Thus, the availability of materials on the subject made it possible to draw a parallel with the genre of the slave narrative. The materials include numerous personal stories from slaves who made the conscious decision to flee to the north - not the northern states of the US but the areas under the control of the Russian Empire.

Still, there is a huge difference between American and Russian-Circassian slave narratives. As shown above, slave narratives, which initially were publicistic texts intended for publication, would eventually evolve into purely fictional neo-slave narratives. Thus, what is perfectly understandable is both their decent literary quality and the refusal of certain historians to consider this type of texts full-on nonfiction. Here are a few distinctive excerpts from the book of F. Douglass "Narrative of the Life of Frederick Douglass, an American Slave": "< ..> my copy-book was the board fence, brick wall, and pavement; my pen and ink was a lump of chalk. $\langle\ldots\rangle$ Thus, after a long, tedious effort for years, I finally succeeded in learning how to write" 15 ; "The silver trump of freedom had roused my soul to eternal wakefulness. Freedom now appeared, to disappear no more forever. $\langle\ldots\rangle$ It looked from every star, it smiled in every calm, breathed in every wind, and moved in every storm"16; "It was a glorious resurrection, from the tomb of slavery, to the heaven of freedom. My long-crushed spirit rose, cowardice departed, bold defiance took its place; and I now resolved that, however long I might remain a slave in form, the day had passed forever when I could be a slave in fact" ${ }^{\prime 17}$. To be sure, runaways from Circassian slavery did not recite monologues to Russian soldiers who questioned them, and, even if they did, no one documented the rhetorical splendors of those monologues. In "Circassian Slave Narratives", the tragedy of slavery is conveyed through a straightforward outline of facts. Here are a couple of examples: "It's been a year since the master traded my wife for a woman who became his wife and sold our daughter, Gabz, to God knows who; he took my son, Tsagazu, away from me, and my son is still with him; there's nothing I can do about it lest he sell or give me away as a gift to somebody, too"18; "After becoming an orphan over 25 years ago, he was taken in by some merchant, named Osip Popechunovich. This man took him to the Turkish city of Akkerman. He lived there for half a year. When the merchant passed away, the Turks took possession of all of his estate. They took Voevodich [the slave's last name] by ship to Circassia and then sold him to a Circassian named Shapshintsu. After having lived in that house for eight years, he was sold to a Circassian named Sozu, based in Abaza. He lived there for some 17 years. This summer, he was kidnapped by some Circassians, who then traded him into Russia for salt" ${ }^{\prime 1}$. As can be seen, while being quite similar in storyline, American and Russian-Circassian slave narratives tend to be diametrically opposed to each other in form and content: it is the difference between

${ }^{13}$ Cherkasov A. A. The Circassian Slave Narratives (A Documentary Collection). P. 1415-1416.

14 Ibid. P. 1416.

15 Udler I. M. "Povestvovanie o zhizni Frederika Duglasa, amerikanskogo nevol'nika. Napisano im samim" v kontekste zhanra "Nevol'nich'ego povestvovaniia" // Vestnik Cheliabinskogo gosudarstvennogo universiteta. 2010. No. 11 (192). P. 135.

16 Ibid. P. 135-136.

17 Ibid. P. 136.

${ }^{18}$ Cherkasov A. A. The Circassian Slave Narratives... P. 1788.

19 Ibid. P. 1646. 
literary publicistic writing by educated people and documented interviews with unlettered peasants, between veiled anthems to freedom and formal record-keeping materials produced in an outlying region of a vast empire.

Besides, many texts in "Circassian Slave Narratives" do not belong to slaves even formally. Note that the collection includes documents that while being pretty straightforward on the outside, turn out to be quite gut-wrenching on the inside. Here are a couple of examples: "This September, between the $7^{\text {th }}$ and $8^{\text {th }}$, a group of Circassian men paid a late-night visit to the house of Iosif Vesely, a Cossack residing in the village of Pashkovskoe, Baturinsky Kurin, and took his two young children - his daughter Agafiya (age 7 years) and his son Vasily (age 6 weeks) - away to an unknown location. I searched for them extensively on the other side of the River Kuban but found no traces of them" (by a cornet named Sheremet [1813] $)^{20}$; "At around three in the afternoon, a horse carrying a Circassian man and a Circassian woman appeared from out of Transkuban and headed toward the Shirochansky post. They were stopped by a group of men led by a cornet named Palivoda, who refused to let them on to Russian territory. There was no translator to help with the conversation, so gestures were used. The cornet attempted to browbeat the man into turning around and going back to where they came from, or else they would both be shot right there. To that, the Circassian responded by gesturing that he would rather be killed than turn around and go back" (by a regimental esaul named Gerko [1813]) ${ }^{21}$.

Thus, from the standpoint of the slave narrative genre, Circassian slave narratives appear to be quite ambiguous. The attempt to apply to the Caucasian material the American concept of slave narratives clearly indicates why in its pure form this genre works only with African-Americans. In the Caucasus, there simply were no "heroic slaves" as it was uncommon to subject slavery to moral condemnation. This is why Russian-Circassian slave narratives are both in form and pathos (which, essentially, is absent in them) diametrically opposed to American slave narratives. Yet, if the slave narrative is viewed not from the standpoint of specific characteristics but as texts that "help reconstruct the most complete picture of what it was like to live as a slave and as a free person and reveal to the world some of the best-kept secrets that no slave would ever want to share with any ill-disposed slave-holder or slave-driver" (per I. M. Udler, a popular stance among today's American scholarly community ${ }^{22}$ ), it can be admitted that A. A. Cherkasov has, actually, managed to create an exact Caucasian analogue of the American slave narrative. Despite the fact that the researcher has yet to provide a detailed analysis of the distinctive genre-related nature of his work, what, as evidenced above, makes it particularly interesting is that it suggests the possibility of creating regional analogues of the American slave narrative, analogues not in form but in substance, slavery-focused nonfiction represented by numerous writings from actual slaves. Who knows, maybe this genre will help establish some new facets in the history of Russian serfdom.

Even a most cursory description of the work carried out by A. A. Cherkasov is just impressive. He selected a total of 1,200 documents, with 180 of those being materials from interviews with fugitive slaves and freedmen ${ }^{23}$. The documents date back to the period from 1792 to 1861 . Chronologically, they are distributed quite unevenly: with some years

\footnotetext{
20 Ibid. P. 1647.

21 Ibid. P. 1631.

22 Udler I. M. Afroamerikanskie "nevol'nich'i povestvovaniia”... P. 120-121.

23 Cherkasov A. A. The Circassian Slave Narratives... P. 1416.
} 
not featuring at all, while with as many as several dozen documents dating from others ${ }^{24}$. Nonetheless, very nominally, the documents may be divided into three major periods. The first period covers the time to 1817, i.e. the year the Caucasian War began. This time frame regularly includes years that produced over 30 documents. The period from 1817 to 1842 offers considerably fewer documents but it does include some years that produced more than 20 documents. Starting in 1842, this type of documents almost disappeared, with even the peak year, 1844, producing just 17 documents ${ }^{25}$. Analysis of these numerical data is beyond the scope of this paper. There is a suggestion that a portion of the documents was lost. Otherwise, the texts' distribution across years could have been different ${ }^{26}$. Put simply, "Circassian Slave Narratives" makes it possible to look at slavery in the Caucasus in the first half of the $19^{\text {th }}$ century through the eyes of hundreds of individuals who lived in that period, from unlettered mountaineers to well-educated Russian officers.

Naturally, given the fact that most of the slaves were illiterate and that their narratives were written down by Russian soldiers, most of the slave narratives are written in a similar style, and the view of slavery they convey is rather primitive and terse. Yet, it makes all the more vivid and valuable these people's indecisive, ingenuous attempts at explaining what it was that made them run away to the Russians. As one reads on, the collection makes it increasingly clear that the motives behind fugitive slaves' actions were highly diverse and, in some cases, even extraordinary. Let us take, for instance, the following materials from interviews with five runaways that date back to 1835 . Of particular interest is the choice of words by one of them, Brakh Osman, who felt "aggrieved" with his master for the latter selling his wife and three children as contraband property into Constantinople ${ }^{27}$. Thus, the slave became disgruntled with his master and ran away, but not before he was treated too harshly. In another case, it is no exaggeration to state that the story of Shegotir Gatukhai is a romantic one, which the scribe somehow succeeds in conveying to us. To "enter into a [consensual] marriage" with Koble Kare, the girl he loves, he "secretly gets her away from her parents' house", and they go into hiding in Russia so that they may "avoid punishment at the hands of her parents"28. There is a bit less beauty in the story of Nogai Satszug who has been at daggers drawn with his younger brother over a girl ever since he "spotted them enjoying some private time together" - hence his decision to move out of the area to avoid further tensions ${ }^{29}$. In another case, a fellow named Gatsuk Gazukhon finds out that he may be sold soon. He also heard that his father was Christian. These factors urge him to escape to the Russian side ${ }^{30}$. And only Bamirz Koble's complaining is limited to a short-spoken account of being "oppressed" by the "all-powerful masters" ${ }^{11}$. Oppression, harsh treatment, love, fear, willingness to embrace the faith of one's ancestors - these are the major topics in the narratives that form the most complete picture of what it was like being a Circassian slave. This picture is, of course, not as detailed and elaborate as its American counterpart, so the reader should not expect all kinds of reflections and rhetorical splendors on the part of Caucasian slaves. Among the above-mentioned five slave

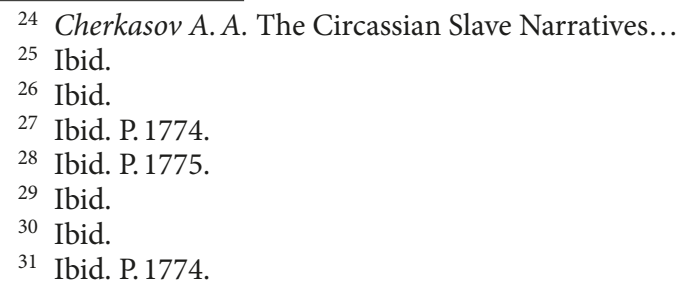


accounts, four mention slave illiteracy; the brevity of the account by Bamirz Koble may be attributed to the fact that he was questioned via an interpreter ${ }^{32}$. Quite often, there also were illiterate individuals among the Circassians' slaves who were ordinary captives from outside of the mountainous region. It is noterworthy that the group was quite diverse in ethnic composition: in 1819, among those who ran away to the Russians was Yan Brizhinsky, born in the Austrian Empire who created "the impression of being a member of a Hussar nation" 33 .

The descriptions through the eyes of actual slaves, i.e. slave narratives in the literal sense of the term, are organically complemented by the accounts of curious and typical events related to slavery from Russian officers. Specifically, between 1815 and 1816 thanks to major F. Tsykh there appeared an entire "epic" about the trading of a captive Cossack child, Fedor Dezhkalo, for a "Circassian-type" girl, named Sashet" 34 . Well, let the documents tell the story. "This is regarding a case involving the exchange of a Circassian girl for a child, the son of Cossack Dezhkalov. On November 14, the boy was brought to the port by a peaceful prince Zaurbek in order to complete the exchange. However, the exchange was thwarted through the interference of Abat Beslenei who turned up at the appointed place too. He threatened to kill Zaurbek engaging in a quarrel with him. When Zaurbek was taking the boy back to the other side of the Kuban, Abat, accompanied by his brother, followed them. On the Circassian side, they shot Zaurbek with a pistol, and took the boy away with them. Abat Beslenei is the man who escaped from the local prison, a brother of Katerina Khizhnyakova, while the killer of prince Zaurbek is his younger brother. Note that the elder of the two visited the port a few days ago. He had a word with prince Khanuk, and then left hastily. It looks like someone is opposing the exchange and trying to take measures lest she be kidnapped" 35 . In this case, the mountaineers are unwilling to proceed with the swap for no other reason than plain greed: eventually, the exchange did take place, but not before an additional 150 rubles was added ${ }^{36}$. Unable to raise the whole amount required, the boy's father, who had just recently ransomed his older son from the same mountaineers for 550 rubles, had to ask F. Tsykh to provide the "outstanding 150 rubles from the public coffers" ${ }^{\prime 37}$. In another case, lieutenant colonel Mazan had this to report to his superiors in 1844: "This is regarding the case of a Shapsug Circassian named Gapukh Nakhumitov, who on August 12 last year fled an area in the mountains to Abin Fortification, seeking the protection of Russia. I wrote about him to Your Excellency in Report No. 544 of September last year. On October 5 this year, this man passed away as a result of an illness supposedly caused by the beatings from his master, of which he had told us previously"38. This kind of insignificant, unintentional descriptions of the harsh treatment of slaves, with many of those being by individuals who by no means supported the abolitionists, are a good indication of the spiritual difference between American slavery, at least in its generally accepted version, and slavery in the Caucasus, viewed as an indisputable fact up to 1860. "A Natukhai named Mamsyr Shekhetl, a scout at Kabardian Fortification, says that about eight days ago one of his brother's peasants, Gassan, ran away

32 Ibid. P. 1774-1775.

33 Ibid. P. 1696.

34 Ibid. P. 1682.

35 Ibid. P. 1680.

36 Ibid. P. 1682.

37 Ibid.

38 Ibid. P. 1864. 
to Abin Fortification, taking with him a girl named Auches, kidnapped by him. Based on the terms of our agreement with the Natukhais, we are to return the fugitive peasants to them. In conjunction with this matter, I request the honor of a directive from you, Your Honor, authorizing the return of the said people to the Shekhetls. I look forward to your favorable consideration of this matter" (by some general whose name was not written legibly enough to be understood [1853] $)^{39}$.

The last group of texts in "Circassian Slave Narratives" is made up of purely record-keeping documents. Some of them are quite representative and illustrative, as, for example, is the case with the following extract:

"1. Name of incoming commodity: Cossack women Dar'ya Stepurina, with a nursing infant, and Varvara Ilenkova, with a boy named Nikifor.

2. Whence from: acquired from some mountaineers in an area outside of Kuban.

3. Description: some clothes with them.

4. Intended use: personal use" 40 .

However, it is to be noted that a large portion of the documents contain only very general information about fugitive slaves. Here is an example: "As evidenced in Case No. 2664 of May this year, the Taman Crime Detection Office has informed the Appointed Ataman that a Circassian man named Khatesav, age 35, who fled an area in the mountains seeking the protection of Russia, has expressed a wish to be granted permanent residence in the stanitsa of Tatar Ady. An ordinance has been prepared authorizing the granting of permanent residence to this man and swearing him in" ${ }^{41}$. With information about all famous Circassian runaway slaves provided by A. A. Cherkasov in a separate appendix ${ }^{42}$, it may seem somewhat excessive publishing all the related texts retrieved. Most importantly, this contravenes the very genre of the slave narrative, as bureaucratic platitudes take the place of first-hand personal statements (even if it is not by a slave or is formulated in a primitive fashion). Besides, the abundance of such documents seems to make it harder to look in the book for the most valuable among them. Thus, a minor downside to A. A. Cherkasov's selection of documents for "Circassian Slave Narratives" is that there are too many of them, more than may be necessary.

In the end, these hundreds of documents, each of which reveals just a fraction of the characteristics of slavery in Circassia, combine into a single entity that while not very harmonious, is definitely quite vivid. A. A. Cherkasov's very choice of this genre urges one to consider the book as not only a research study but a piece of nonfiction prose too. It is not particularly literary; its language may seem clunky and laconic - but this is what helps powerfully convey the stern ways in the Caucasus in those times. And, if the reader is able to grasp these characteristics of the text, they will be provided with an epic canvas that will feature various unlettered individuals incapable of expressing their complex feelings on their own. Each protagonist will emerge on it for a brief "document", before disappearing. Yet, even this should be sufficient to connect with the emotions of most of these people. The likes of the below excerpts from the documents may well provide the potential groundwork for a romantic novel set in the Caucasus.

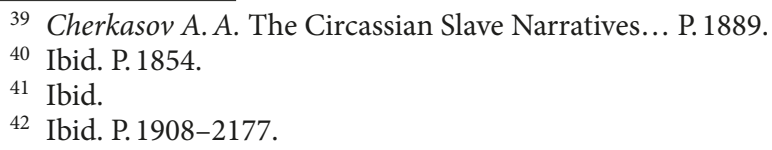


"His name is Abatir Usse. He says he is a cousin of Transkuban master Khanuka. He is here to reclaim his daughter, Peke, who was kidnapped by someone here named Akhmet. In exchange, he is prepared to release three boys, whom the predators from his Zakuban army captured here some time ago, along with some cattle and horses, and that is on condition that the exchange should take place at the Chernolessky exchange yard. He says that if the girl is not released back to him, he will round up a group of Circassian warriors from around the 800 homesteads under his control and beyond and they will attack this area. He says that as an act of vengeance, they will subject the whole area to depredation and plunder"43. "Abatir requested that Your Excellency be informed of his query as to whether it would be possible, under the peace agreement, to just release his daughter, Peke, back to him. He promised that in return they would seek to strengthen their allegiance to us and would stop their raids on our lands for good. In addition, he promised that they would also seek to stop others from attacking us. $<\ldots .>$ To my query as to his promise to release our men back to us, he responded by saying that the only reason behind that promise was to find out where exactly his daughter had been taken from their side to ours, so as to subject that area to increased plunder and predation. He also said that he was forbidden by all masters back home to release the captives in return for the girl"44. "This report is to inform Duke of Richelieu that the girl has been released back to her father" ${ }^{\text {" }}$.

"Circassian Slave Narratives", truly, makes it possible to look at slavery in Circassia through the eyes of parents whose daughters were taken away from them into slavery, enamored couples who ran away from the family, or hapless captives, and in this respect the collection even outdoes American slave narratives with their pretty much unidimensional focus on the "heroic slave".

In conclusion, a few words must be added about the level of effort put in by A. A. Cherkasov in publishing the above work. What, above all, is evident is its convenience, for, along with the brilliant list of fugitive slaves (which comprises each slave's first and last names, gender, tribe, estate, age, and reasons for running away, the date and place of their emancipation from slavery, and the archival code for the documents in which they are mentioned), the book also contains a name index and a geographical index ${ }^{46}$. Given the large number of documents used in the book, including the ones just mentioning the names of fugitive slaves, the reference apparatus provided by A.A.Cherkasov is highly helpful for working with the text. Somewhat on the weaker side is the way the documents are commented on in the book (the commenting lacking continuity, no biographical background provided in respect to the majority of prominent figures the book mentions, and the characteristics of the period's daily life in the areas described unevenly). That being said, given the form of publication (a special issue of a scholarly journal), "Circassian Slave Narratives" appears to be primarily geared toward the professional community of historians rather than a mass audience. Consequently, the fact that there are fewer comments than may be deemed necessary may be attributed to the scholar's unwillingness to increase the amount of text in the book, large as it is, through providing additional information. Whatever the case may be, it can be argued that the book would only benefit from

\footnotetext{
${ }^{43}$ Ibid. P. 1650.

44 Ibid. P. 1652.

45 Ibid.

46 Ibid. P. 2208-2265.
} 
A. A. Cherkasov making some more comments at the expense of leaving out some of the less interesting documents.

What appears to be the only really ambiguous element in "Circassian Slave Narratives" is the annotated introductory article, which structurally serves as the work's preface. Essentially, it rather seems a scholarly article intended to provide a general characterization of Circassia in the period 1792-1861, to describe some of the characteristics of local slavery, and to share the findings from an initial analysis of the documents provided. Nonetheless, it may be argued that given that "Circassian Slave Narratives" is positioned as a collection of documents, however original it may be, it would have made somewhat more sense to write a regular preface, the one not focused on analyzing the documents included but intended to help get the reader ready to meet them.

On the downside, A. A. Cherkasov provides just a short summary of the mechanics of the slave narrative genre, which is quite exotic to Russia, without mentioning a single work in $\mathrm{it}^{47}$. That being said, as can be seen from the present review, it is the experience of using the genre of the slave narrative on Russian soil, which is alien to it, that is of significant interest and may be sought after by other scholars. A. A. Cherkasov is also somewhat too brief on past research on slavery in the Caucasus, and that is something that could work in the article, but not in the book ${ }^{48}$. On top of that, absolutely no attention is devoted in the work to the post-Soviet historiography of the issue. Meanwhile, he should have at least mentioned the works of S. L. Dudarev, who is actively involved in this problem ${ }^{49}$. Besides, in recent years A. T. Urushadze and E. S. Tyutinina published documents about slavery in the Caucasus ${ }^{50}$. As a result, the reader who is not immediately familiar with the history of the Caucasus will proceed to read the main body of the book, being already aware of its most general conclusions but unable to juxtapose them with various debatable issues in present-day historiography. While it is definitely worth commending the high scholarly level of A. A.Cherkasov's introductory article, it may, however, be argued that its taking the place of a regular preface is hardly justified. Given all that was said above, this, cannot be regarded as a serious shortcoming of the book, for what constitutes the primary value of "Circassian Slave Narratives" is the scholar's use of a set of documents that do fit in with the concept of slave narratives. Thus, even if the book contained no introduction and no comments whatsoever, that would hardly make it less interesting to read.

That being said, it is in the article provided in place of a preface that A. A. Cherkasov draws a significant conclusion. Even ethnically, the slaves who escaped from Circassia formed an inhomogeneous group: 1,089 Circassians, 1,008 ethnic Russians, 49 Abazinians, 42 Greeks, 34 Tatars, and 31 Poles $^{51}$. And, quite possibly, it is the distinct differences in descent, religion, and upbringing that led, as shown above, to a significant characteristic of Russian-Circassian slave narratives - the diversity of their protagonists. If in African-American slave narratives the slave was a heroic figure, and in their Russian coun-

${ }^{47}$ Cherkasov A. A. The Circassian Slave Narratives... P. 1415-1416.

48 Ibid. P. 1417.

49 Dudarev S. L. Pokhozhdeniia krest'ianki Anny Solopovoi (liubovnaia intrizhka, zavershivshaiasia plenom u gortsev) // Kant. 2016. Vol. 4, no. 21. P. 14-18; Dudarev S. L. F. V. Totoev about slavery in Chechnya in the historical past // Slavery: Theory and Practice. 2018. Vol. 3, iss. 1. P. 18-30.

50 Urushadze A. T. V plenu u gorttsev: iz istorii uchastiia donskikh kazakov v Kavkazskoi voine // Novoe proshloe / The New Past. 2017. No.2. P.208-214; Tyutyunina E. S. To the Issue of Slavery in the Terek Cossacks // Slavery: Theory and Practice. 2018. Vol. 3, iss. 1. P. 40-48.

${ }^{51}$ Cherkasov A. A. The Circassian Slave Narratives... P. 1429. 
terparts the slave was a martyr, the protagonist in Russian-Circassian slave narratives can hardly be tied down to one common archetype.

Thus, the first attempt at adapting the genre of the slave narrative for the purposes of describing Russian history has been a success. A. A. Cherkasov came up with a body of Caucasian (Circassian) material that fits in with this genre pretty well, and was able to present it to the reader in as comprehensive a manner as possible. That said, it appears that while American narrative forms, heroes, and pathos cannot be fully transposed to Russia, what can well be is the actual idea underlying the slave narrative - emotional, first-hand, nonfiction accounts by actual slaves.

\section{References}

Cherkasov A. A. The Circassian Slave Narratives (A Documentary Collection). Bylye Gody, 2020, vol.57-1, issue 3-1 (Special issue), pp. 1415-2266. (In Russian)

Cherkasov A. A., Ivantsov V. G., Smigel M., Molchanova V. S. Evolution of the Institution of the Slave Trade in the Caucasus in the IV-XIX centuries. Bylye Gody, 2018, vol.50, iss. 4, pp. 1334-1346. (In Russian)

Cherkasov A. A., Ivantsov V. G., Smigel M., Molchanova V.S. The List of Captives from the Turkish Vessel Belifte as a Source of Information on the Slave Trade in the North Western Caucasus in the Early $19^{\text {th }}$ century. Annales. Series historia et sociologia, 2017, vol.27, iss. 4, pp. 851-864.

Dudarev S. L. F. V. Totoev about slavery in Chechnya in the historical past. Slavery: Theory and Practice, 2018, vol. 3, iss. 1, pp. 18-30. (In Russian)

Dudarev S. L. Pokhozhdeniia krest'ianki Anny Solopovoi (liubovnaia intrizhka, zavershivshaiasia plenom u gortsev). Kant, 2016, vol.4, no. 21, pp. 14-18. (In Russian)

Stulov Iu. V. The Genre of Neo-slave Narrative in Modern African American Literature. Visnyk of the Lviv University. Series Foreign Languages, 2012, iss. 20, pt. 2, pp. 160-166. (In Russian)

Tyutyunina E. S. To the Issue of Slavery in the Terek Cossacks. Slavery: Theory and Practice, 2018, vol.3, iss. 1, pp. 40-48. (In Russian)

Udler I. M. "Slave Narratives" in the Culture and History of the United States. Mirovaia literatura $v$ kontekste kul'tury, 2009, no. 4, pp. 17-19. (In Russian)

Udler I.M. "The Interesting Narrative of the Life of Olaudah Equiano, Or Gustavus Vassa, The African. Written by Himself": the Problem of Identification, Russian Destiny and Russian Parallels. Mirovaia literatura $v$ kontekste kul'tury, 2008, no. 3, pp. 128-133. (In Russian)

Udler I. M. "Narrative of the Life of Frederick Douglass. Written by Himself" in the Context of the Genre Slave Narrative. Vestnik Cheliabinskogo gosudarstvennogo universiteta, 2010, no. 11 (192), pp. 133-138. (In Russian)

Udler I. M. African American "Slave Narratives" as a Documentary Source of the History of Slavery in the United States. Vestnik Cheliabinskogo gosudarstvennogo universiteta. Filologiia. Iskusstvovedenie, 2009, no. 5 (143), pp. 118-123. (In Russian)

Udler I. M. Formation and Evolution of the Documentary-Journalistic genre of "Slave Narratives" in the $18^{\text {th }}-19^{\text {th }}$ Centuries. Znak: problemnoe pole mediaobrazovaniia, 2009, vol. 1, no. 3, pp. 88-93. (In Russian)

Urushadze A. T. V plenu u gorttsev: iz istorii uchastiia donskikh kazakov v Kavkazskoi voine. Novoe proshloe / The New Past, 2017, no. 2, pp. 208-214. (In Russian)

Статья поступила в редакцию 9 сентября 2020 г. Рекомендована в печать 10 декабря 2020 г.

Received: September 9, 2020

Accepted: December 10, 2020 